\title{
Analysis of tissue dependent DNA yield for optimal sampling of micro-moths in large-scale biodiversity surveys
}

\author{
Carlos LopeZ-VAamonde ${ }^{1}$, Floris C. BREMAN ${ }^{3}$, David C. LEES ${ }^{1,2}$, Jeroen VAN HOUDT ${ }^{3}$ \\ and JURATE DE PRINS ${ }^{3}$
}

\begin{abstract}
${ }^{1}$ INRA, UR0633 Zoologie Forestière, F-45075 Orléans, France; e-mail: carlos.lopez-vaamonde@orleans.inra.fr
${ }^{2}$ Department of Entomology, Natural History Museum, S. Kensington, London, SW7 5BD, UK; e-mail: dclees@gmail.com

${ }^{3}$ Royal Museum for Central Africa, Leuvensesteenweg 13, B-3080 Tervuren, Belgium; e-mails: floris.breman@africamuseum.be; jeroen.vanhoudt@bio.kuleuven.be; jurate.de.prins@africamuseum.be
\end{abstract}

Key words. Gracillariidae, Cameraria ohridella, DNA barcoding, DNA preservation, DNA quantification, picogreen

\begin{abstract}
DNA barcoding surveys of small insects usually extract DNA from either a complete insect or a leg. Little is known about how to optimize DNA quantity and quality from different insect parts while preserving a morphological voucher. Here, we quantify DNA yield from different body parts (antenna, hind leg, forewing, hind wing and abdomen) of the micro-moth Cameraria ohridella (Lepidoptera: Gracillariidae) using fluorescent nucleic acid stain (PicoGreen). Samples were preserved in 100\% ethanol or dried for three weeks. Our experiment was designed to encompass practical sampling options during fieldwork. DNA quality was assessed by PCR amplification of the mitochondrial COI barcode fragment. In addition, we compared PCR amplification using Platinum ${ }^{\circledR}$ Taq and Qiagen DNA Polymerase and quantified sequence success of amplified DNA. We show that overall, dry parts showed higher eluted DNA yields. PCR and sequencing success rate were slightly higher for dry tissue than ethanol-preserved parts. We also show that Platinum ${ }^{\circledR}$ Taq yielded the highest PCR success rate and that all dry tissues are sequenceable. The optimal strategy for DNA barcoding surveys is therefore to mount micro-Lepidoptera specimens in the field for morphological analysis and sample tissues (hind legs are favoured) from dried samples at a later time (several weeks) in the lab for DNA barcoding using preferentially Platinum ${ }^{\circledR}$ Taq. If larger amounts of DNA are required (i.e. for nuclear gene sequencing), several legs from one side of the specimen or the abdomen should be preserved in pure ethanol.
\end{abstract}

\section{INTRODUCTION}

Lepidoptera (butterflies and moths) play a prominent role in biodiversity surveys as indicators of habitat disturbance and hotspots of biodiversity (Küper et al., 2004; Kristensen et al., 2007). They constitute a mega-diverse order of insects with at the latest count 157,424 recognized species (Nieukerken et al., in press) and an additional estimated 230,000 species (www.lepsys.eu) still to be discovered, mostly in tropical areas. The least known Lepidoptera that include the highest number of undescribed species are the micro-Lepidoptera, a paraphyletic group (Regier et al., 2009) ignored by the bulk of lepidopterists with some prominent exceptions such as butterflies (Mutanen et al., 2010). Over recent decades, molecular methods have complemented traditional comparative morphology and taxonomic classification of micro-moths (Nieukerken et al., in press). Indeed, an increasing number of DNA-based studies on smaller moths have recently been published in the fields of evolutionary biology (Lopez-Vaamonde et al., 2003, 2006; Kawakita et al., 2004; Bucheli \& Wenzel, 2005; Pellmyr et al., 2006; Schmitz et al., 2007; Kawahara et al., 2011), molecular ecology (Mari Mena et al., 2008; Valade et al., 2009), and in clarifications of complicated cases in alphataxonomy such as cryptic differentiation and/or species race formation (Kaila \& Ståhls, 2006; Ohshima, 2008; Schmitz et al., 2008).
The availability of molecular techniques that can obtain DNA sequence data from tiny amounts of tissue or from old museum specimens (Mandrioli et al., 2006; Meusnier et al., 2008) has led to an increased interest in museum collections which are important not only for studying species at a molecular level but also to integrate DNA data into studies previously conducted at a morphological level only (Carter et al., 1997; Quicke et al., 1999; Knölke et al., 2005; De Prins et al., 2009). However, extraction of DNA is invasive and entails the destruction of the entire specimen, or a part of it. This is a serious problem when handling rare museum specimens or types (Whitfield \& Cameron, 1994; Mandrioli, 2008). In addition, for freshly collected material, it is critical that voucher specimens used in genetic analyses are available for subsequent morphological study to corroborate identifications, and in some cases for those vouchers to become future types. This is particularly relevant to surveys of microlepidoptera fauna in the tropics where exceptionally high levels of singletons (species represented by single individuals) of undescribed species are found (Davis \& Stonis, 2007).

Preserving samples in such a way that they are suited both for morphological studies as well as for the extraction of high quality DNA at a later date, has proved difficult. Different authors have suggested several approaches to minimize destruction of voucher specimens (Philips et al., 1995; Gilbert et al., 2007; Rowley et al., 2007). For instance, efforts have been made to avoid wasting sub- 
stantial amounts of DNA, which is discarded in the form of soft $\mathrm{KOH}$-macerated tissue during slide preparation for morphological analysis. A logical step is to combine morphological genitalia examination with DNA-sequence information by modifying the dissection protocol: maceration of abdomens in $\mathrm{KOH}$ is replaced by proteinase- $\mathrm{k}$ enzymatic digestion of soft tissue followed by DNA extraction. This procedure has been successfully applied to relatively large specimens in the Pyralidae and Geometridae (Knölke et al., 2005) and recently to microLepidoptera (Ohshima \& Yoshizawa, 2006, Nieukerken 2007, 2010). However, Lepidoptera, often possess very complex male genitalic structures, and diagnostic characters such as long ducti often occupy the complete abdomen in females (Kaila, 2011), and long sacci penetrating 3-4 abdominal segments in males. We note also that lepidopteran abdomens may be rich in external scale characters including spines and androconia (Adamski \& Brown, 1989; Horak, 2006) that can be destroyed during digestion.

Other parts of the body have been successfully used as source of DNA such as pieces of wings (Rose et al., 1994; Vila et al., 2009). However, most genetic surveys of adult insects usually extract DNA from a leg (Lai \& Pullin, 2004; Watts et al., 2007; Vila et al., 2009; Koscinski et al., 2011). Indeed, legs remain the main tissue used as source of DNA in large molecular systematic studies of Lepidoptera such as the all-Lepidoptera barcoding project (Janzen et al., 2005; Burns et al., 2007; http://www.lepbarcoding.org). However, the hind legs of most micro-moths are relatively small. Additionally, in rough field conditions in remote tropical areas with a micro-Lepidopteran fauna that is mostly unknown to science, and with techniques that are both time-consuming and require skilled manipulation, the fieldworker is faced with a dilemma. Either the small specimen is pinned and set for further morphology-based species description, or the specimen is fixed for DNA preservation. The need to solve this and minimize destructive procedures prompted us to analyse which morphological part of a small lepidopteran specimen could best serve for DNA extraction, leaving the genitalia intact and, ideally a mirror part of the removed body parts for further morphology-based study.

For our experiment, we used adults of the horse chestnut leafminer Cameraria ohridella Deschka \& Dimić, 1986 (Lepidoptera: Gracillariidae). C. ohridella is a highly invasive species which has spread throughout Europe and has become one of the best known micromoth species (Lees et al., 2011a, b).

Here, we aimed to assess DNA quantity and sequencing success from different body parts of $C$. ohridella to identify a tissue that will yield sequenceable DNA, without damaging the voucher specimen so that further morphological studies can be carried out.

\section{MATERIAL AND METHODS}

\section{Sample preparation}

Thirty freshly-emerged adult moths collected in Mézières-lezCléry, France, were placed in a collection tube that was then placed in boiling water for several seconds, a practical and con- venient technique that does not require dangerous killing reagents (Dall'Asta et al., 2002). For each adult moth, ten tissue samples were examined: five samples were removed with the help of a needle and forceps from the right side, and five from the left side. The five samples from the right side were fixed in $100 \%$ ethanol and coded as follows: right antenna (RAN), right forewing (RFW), right hindwing (RHW), right hindleg (RHL), abdominal segments I-III (FAB). The left side of each specimen was set and dry-preserved in a hermetically sealed plastic box along with moisture absorbing silica gel crystals (Fluka 11292600-8). After three weeks of drying, five tissue samples were removed as above, fixed in $100 \%$ ethanol and coded as follows: left antenna (LAN), left forewing (LFW), left hindwing (LHW), left hindleg (LHL). Dry abdominal segments IV-VIII (HAB) were also placed in $100 \%$ ethanol. Dry samples were fixed in ethanol because small tissues such as dry legs and antennae of micromoths are prone to spontaneous displacement because of static electricity. While samples were drying, ethanol-preserved samples were kept in the fridge $\left(1^{\circ} \mathrm{C}\right)$.

The mean size of tissue samples of $C$. ohridella \pm standard deviation measured for 10 individuals was as follows: Length of antenna $(3.51 \pm 0.35 \mathrm{~mm})$; area of forewing $\left(2.40 \pm 0.51 \mathrm{~mm}^{2}\right)$; area of hindwing $\left(0.59 \pm 0.12 \mathrm{~mm}^{2}\right)$; length of femur $(0.66 \pm$ $0.06 \mathrm{~mm})$; length of tibia + tarsus $(2.73 \pm 0.25 \mathrm{~mm})$; length of hindleg $(3.38 \pm 0.31 \mathrm{~mm})$.

\section{DNA extraction}

Due to the small size of samples, we did not grind them. Three hundred DNA extractions (10 extractions per individual) were carried out using the Nucleospin tissue kit (MachereyNagel). Because of the small size of tissue we adjusted the manufacturer's protocol by halving the recommended digestion, lysis and DNA binding volumes. Digestion was performed in $90 \mu \mathrm{l}$ of digestion buffer and $12.5 \mu 1$ proteinase $\mathrm{K}$ solution for two hours with regular vortexing, then $100 \mu$ of lysis buffer was used. For the cleaning steps we used $500 \mu \mathrm{l}$ of cleaning solution 1 and $600 \mu \mathrm{l}$ of the cleaning buffer mixed with ethanol and isopropanol. The elution of the DNA was done in two steps of $25 \mu 15 \mathrm{mM}$ TrisHCl to increase the concentration and to maximize DNA recovery from the binding columns.

\section{DNA concentration assessment}

We tried to measure the concentration of DNA by measuring absorbance at $260 \mathrm{~nm}\left(\mathrm{~A}_{260}\right)$ with the ND-1000 spectrophotometer v3.5 (NanoDrop Technologies, Wilmington, NC, USA) and an Eppendorf Biophotometer. However, DNA concentration was below the threshold detection value of most samples or they did not exceed measuring error values of both detection systems. We therefore used a PicoGreen assay (Invitrogen, Paisley, UK), a routine procedure for accurate DNA quantification (Watts et al., 2007; Wilding et al., 2009) and measured the concentration with a Tecan Infinite F200 filter-based detection system (Tecan). The DNA was stained using a fluorescent dye that emits a fluorescent signal when excited by light. This detection system expresses its measurements in relative fluorescent units (rfu). The rfu of samples were determined by comparing the samples with a reference set of known concentrations. The reference samples used were supplied by the manufacturer and consisted of Lambda phage DNA. The concentrations ranged from $0-1000 \mathrm{ng} / \mathrm{ml}$. The values obtained with the solution that contained no DNA was considered background noise and this was substracted from the values obtained from the samples. Background noise was determined by taking the average of three empty samples. It was determined as being at $77 \mathrm{rfu}$. We then calculated the concentrations with corrected relative fluorescent units (crfu). These crfu are the measured values with the 
"background noise" subtracted from that value. From the reference series a linear regression was made, which expresses the reads from the machine as values in $\mathrm{pg} / \mu \mathrm{l}$.

\section{PCR assessment}

The PCR was carried out in $20 \mu 1$ containing $1 \times$ PCR buffer (Qiagen), $\leq 1-20 \mathrm{ng}$ template DNA, $2.0 \mathrm{mM} \mathrm{MgCl}_{2}, 0.2 \mathrm{mM}$ dNTPs, 0.02 units/ $\mu 1$ of Taq DNA polymerase (Qiagen) and $0.4 \mu \mathrm{M}$ of the forward and reverse primers. The PCR profile started with an initial denaturation of $3 \mathrm{~min}$ at $94^{\circ} \mathrm{C}$, followed by 35 cycles of $45 \mathrm{~s}$ at $94^{\circ} \mathrm{C}, 45 \mathrm{~s}$ at $50^{\circ} \mathrm{C}$ and $45 \mathrm{~s}$ at $72^{\circ} \mathrm{C}$. The PCR ended with a final step of $7 \mathrm{~min}$ at $72^{\circ} \mathrm{C}$. The same conditions were used for Platinum ${ }^{\circledR}$ Taq.

The PCR was evaluated on precast $2 \%$ agarose gels (Invitrogen) with the same uv-illumination strength. The result per PCR was scored according to a visual assessment: (a) a success contained a visible band of the expected size which could be a strong or a weak band; (b) a failure did not contain a visible band on the gel. We used primers Lep-HybLCO \& LepHybHCO which are the primers LCO1490 and HCO2198 published by Folmer et al. (1994) adjusted with a T7/T3 universal primer pair (Wahlberg \& Wheat, 2008) to amplify the $658 \mathrm{bp}$ "DNA barcode fragment" (COI mt-marker).

\section{Sequencing assessment}

We also measured success as sequenceable DNA. Since well amplified DNA (the barcode fragment) of Gracillariidae is always sequenceable ( $100 \%$ success rate, unpubl. data) we tried to sequence "poorly" amplified PCR products.

Out of 183 amplified bands, 36 poorly amplified or failed bands were chosen for DNA sequencing. In addition, we used two well amplified bands as positive controls. PCR products were purified using the Nucleofast Kit (Machery-Nagel GmBH) and sequenced using the BigDye Terminator v. 1.1 Cycle Sequencing Kit on an ABI 3130xl automated capillary DNA sequencer (Applied Biosystems). Four $\mu 1$ of the cleaned PCR product was added to the cycle sequencing master mix to yield a total volume of $12 \mu 1$. Sequences were checked, assembled and aligned in SeqScape v2.5 (Applied Biosystems). Average phred scores were used to assess sequence quality. Sequences with an average phred score of 29 or higher were accepted as valid if they were matched with the reverse complement. A successfully recovered barcode was defined as having both forward and reverse read which provide the full length barcode of $658 \mathrm{bp}$ with an average phred score of 29 or higher. The number of ambiguous calls must also be less than $1 \%$.

Edited sequences were deposited in GENBANK (Accession numbers: JN603639-JN603661).

\section{Statistical analysis}

Data sets were not normally distributed (Kolmogorov test highly significant) so data was analyzed non-parametrically using Microsoft Excel (2002 for PC) using sheets obtained from McDonald (2009).

\section{RESULTS}

\section{Tissue dependent DNA yield}

DNA quantity differed significantly between tissues (Kruskal-Wallis test: $H=45.99$, d.f. $=4, \mathrm{p}<0.001$ ). The largest DNA concentrations were obtained from ethanolpreserved abdomens (FAB) and dry stored abdominal segments (HAB) (409.7 and $262.6 \mathrm{pg} / \mu \mathrm{l}$ respectively). Interestingly, despite the fact that ethanol preserved abdomens show the highest concentration of DNA (Fig. 1), overall dry tissue has a significantly higher DNA yield

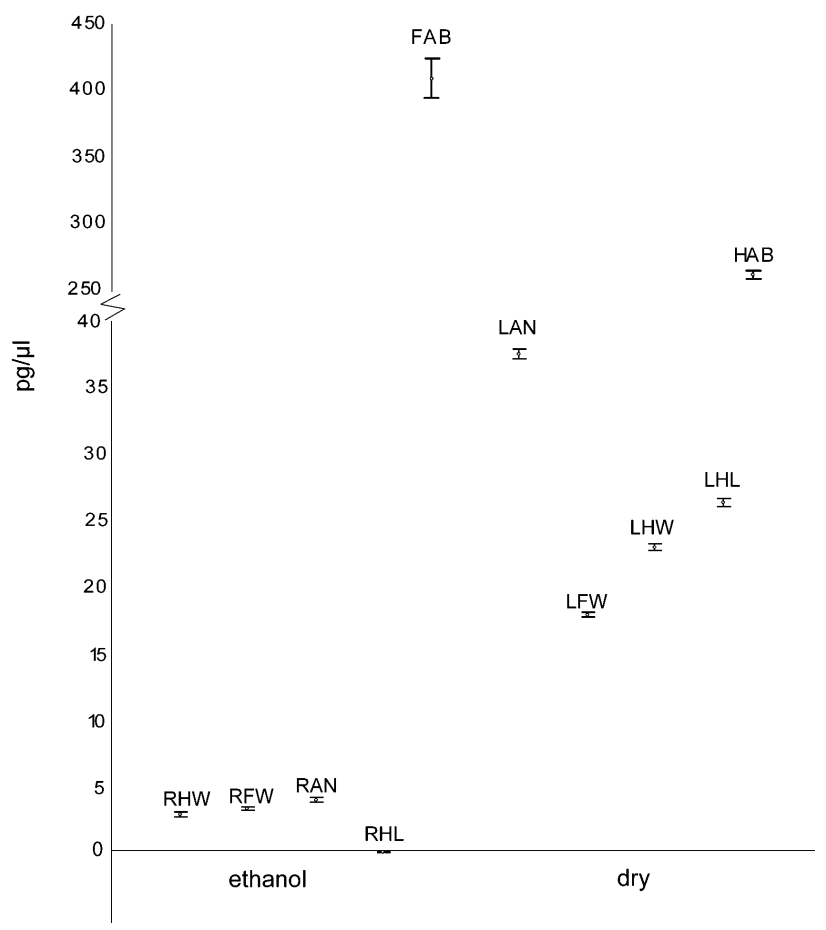

Fig. 1. Comparison of DNA quantity $(\mathrm{pg} / \mu \mathrm{l})$ between different morphological parts of $C$. ohridella and preservation methods. Error bars indicate the $95 \%$ confidence intervals.

than ethanol-preserved tissue, (Wilcoxon signed ranks test: $W=132.5 \mathrm{n}=46, \mathrm{p} \leq 0.001)$.

\section{PCR success rates}

Tissues yielded good quality DNA, and gel electrophoresis showed sharp bands of high molecular weight with no evidence of degradation. We observed no non-specific amplicons in our reactions.

Overall, Platinum $^{\circledR}$ Taq DNA Polymerase delivered slightly greater intensity amplicons and amplification success. Indeed, $97.9 \%$ of PCR reactions, that is 94 (48 bands for dry +46 bands for ethanol preserved tissue) out of 96 PCR reactions yielded a visible amplified PCR product using Platinum ${ }^{\circledR}$ Taq. On the other hand, 91.7\% of PCR reactions, that is 88 (47 bands for dry +41 bands for ethanol preserved tissue) out of $96 \mathrm{PCR}$ reactions yielded a visible amplified PCR product using Qiagen Taq (Table 1).

Dry material showed slightly higher PCR success rate for both Taqs $\left(100 \%\right.$ for Platinum ${ }^{\circledR}$ Taq and 98\% for Qiagen Taq) than ethanol-preserved tissue (96\% for Platinum $^{\circledR}$ Taq and 85\% for Qiagen Taq) (Table 1).

\section{Sequencing success rate}

Out of 36 poorly amplified DNA samples 23 (63.9\%) were successfully sequenced producing readable barcodes (Table 2). Both positive controls were also successfully sequenced.

All 23 barcodes belong to the invasive haplotype A, the most common haplotype in Europe (Valade et al., 2009; Lees et al., 2011b). 
TABLE 1. PCR success rate related to DNA quality from different tissues and preservation methods using two types of Taq DNA polymerase.

\begin{tabular}{|c|c|c|c|c|c|c|c|}
\hline \multirow[b]{2}{*}{$\begin{array}{l}\text { Preservation } \\
\text { method }\end{array}$} & \multirow[b]{2}{*}{ Tissue sample } & \multicolumn{3}{|c|}{ Platinum $^{\circledR} T a q$} & \multicolumn{3}{|c|}{ Qiagen $T a q$} \\
\hline & & $\begin{array}{l}\text { PCR success } \\
\text { rate }(\%)\end{array}$ & $\mathrm{N}^{\circ}$ PCR bands & $\begin{array}{c}\text { Total } n^{\circ} \text { PCR } \\
\text { reactions }\end{array}$ & $\begin{array}{l}\text { PCR success } \\
\text { rate }(\%)\end{array}$ & $\mathrm{N}^{\circ}$ PCR bands & $\begin{array}{c}\text { Total } n^{\circ} \text { PCR } \\
\text { reactions }\end{array}$ \\
\hline \multirow{5}{*}{ Dry } & Abdomen (HAB) & 100 & 10 & 10 & 100 & 10 & 10 \\
\hline & Antenna (LAN) & 100 & 8 & 8 & 100 & 8 & 8 \\
\hline & Fore wing (LFW) & 100 & 10 & 10 & 100 & 10 & 10 \\
\hline & Hind leg (LHL) & 100 & 10 & 10 & 100 & 10 & 10 \\
\hline & Hind wing (LHW) & 100 & 10 & 10 & 90 & 9 & 10 \\
\hline \multirow[t]{3}{*}{ Total } & & 100 & 48 & 48 & 98 & 47 & 48 \\
\hline & Abdomen (FAB) & 100 & 10 & 10 & 100 & 10 & 10 \\
\hline & Antenna (RAN) & 100 & 8 & 8 & 100 & 8 & 8 \\
\hline \multirow[t]{3}{*}{ Ethanol } & Fore wing (RFW) & 90 & 9 & 10 & 60 & 6 & 10 \\
\hline & Hind leg (RHL) & 100 & 10 & 10 & 90 & 9 & 10 \\
\hline & Hind wing (RHW) & 90 & 9 & 10 & 80 & 8 & 10 \\
\hline Total & & 96 & 46 & 48 & 85 & 41 & 48 \\
\hline
\end{tabular}

\section{DISCUSSION}

Researchers working on small insects such as micromoths regularly deal with DNA extractions with concentrations below $10 \mathrm{ng} / \mu \mathrm{l}$. In such cases, quality assessments measured via spectrophotometry using the $260 / 280 \mathrm{~nm}$ absorbance ratio have been shown to be unreliable (Wilding et al., 2009). Here we successfully use Picogreen as an alternative method to estimate DNA quantity from tiny amounts of tissue (Watts et al., 2007; Wilding et al., 2009). Since many microlepidopteran species are represented by a very short type series or just the holotype (Vári, 1961; Aarvik \& Karisch, 2009), we simulated a situation where only a very small tissue sample is available. Due to the minute size of samples and difficulty in handling them, we did not grind them before extraction, which would have made a larger surface area of digestible parts available for the digestion buffer. Since the chitin exoskeleton is not affected by the proteinase $\mathrm{K}$, it is possible that the buffer solution did not digest all of the tissue inside some body-parts of the uncrushed samples, and this could explain the overall low quantities of DNA obtained.
Previous studies have successfully used antennae and/or legs of freshly collected micro-moth adults as good sources of DNA for molecular phylogenetic analyses (Lopez-Vaamonde et al., 2003, 2006). Those studies used Chelex 100 resin (Bio-Rad, Hercules, CA), a medium for simple extraction of DNA for PCR-based typing from forensic material (Singer-Sam et al., 1989; Walsh et al., 1991). However, the problem with this method is the short storage life of the DNA extractions (Watts et al., 2005). Here we decided to use a standard commercial extraction kit that yields high quality DNA.

Several papers have looked at the effects of preservatives on the yield of insect DNA useable for PCR amplification (Post et al., 1993; Vink et al., 2005). Storage of samples in $80-100 \%$ ethanol at low temperature has been identified as an appropriate method for DNA preservation (Quicke et al., 1999; Vink et al., 2005). Our data set shows a significantly higher DNA yield for dry stored specimens than for ethanol-preserved parts (Fig. 1). Likewise, PCR and sequencing success rate was slightly higher for dry tissue than ethanol-preserved parts (Table 1). In contrast to those results, ethanol preserved abdo-

TABLE 2. Sequencing success rate related to DNA quality for 36 poorly amplified DNA samples from different tissues and preservation methods.

\begin{tabular}{llccc}
\hline Preservation method & Tissue sample & $\begin{array}{c}\text { Overall sequencing } \\
\text { success rate (\%) }\end{array}$ & $\begin{array}{c}\mathrm{N}^{\circ} \text { of readable } \\
\text { sequences }\end{array}$ & $\begin{array}{c}\text { Total } \mathrm{n}^{\circ} \text { sequencing } \\
\text { reactions }\end{array}$ \\
\hline \multirow{4}{*}{ Dry } & Abdomen (HAB) & 100 & 2 & 2 \\
& Antenna (LAN) & - & - & - \\
& Fore wing (LFW) & 100 & 2 & 2 \\
\hline Total & Hind leg (LHL) & 100 & 2 & 1 \\
\hline \multirow{5}{*}{ Ethanol } & Hind wing (LHW) & 0 & 0 & 7 \\
& Abdomen (FAB) & 86 & - & - \\
& Antenna (RAN) & - & 1 & 3 \\
\hline Total & Fore wing (RFW) & 33 & 5 & 11 \\
\hline
\end{tabular}

*No poorly amplified or failed bands were available because all bands amplified well for those tissues. 
mens show higher DNA yields than dry abdomens. This disparity is likely due to the fact that abdomens take relatively longer to dry and water may degrade DNA, so putting abdomens straight in $100 \%$ ethanol helps to reduce DNA degradation.

It is also worth highlighting the $100 \%$ PCR success rate obtained when using Platinum ${ }^{\circledR} T a q$ to amplify all types of dry tissue (Table 1). Therefore, our advice is to mount micro-Lepidoptera in the field, leave the specimens to dry for several weeks, and then sample a dry hind leg or an antenna back in the laboratory for DNA barcoding using Platinum $^{\circledR}$ Taq.

However, if a researcher needs larger amounts of DNA (ie. for nuclear gene sequencing, when the moth is small), and only one specimen per species is available (as mentioned before, surveys of tropical microlepidoptera contain very high proportions of singletons) several legs from one side of the specimen or if possible, the abdomen should be preserved in pure ethanol.

In our experiments, specimens were dried using silica gel to mimic procedures in tropical areas where care must be taken to avoid initial humidification e.g. by using a drying oven or silica gel (Amsel, 1935; Landry \& Landry, 1984). This is an efficient procedure both to obtain sequenceable DNA from large series of specimens collected during biosurveys in remote tropical areas and to minimize damage to the voucher specimens (to ensure this, a quantity of silica crystals is permeably separated within an airtight container). This procedure may also apply to other groups of small insects. It is hoped that our results will aid sampling during large scale biodiversity surveys and encourage the preservation of both morphological and molecular vouchers for systematic analysis.

ACKNOWLEDGEMENTS. We gratefully thank I. Ohshima, R. Rougerie, A. Kawahara and two anonymous reviewers for valuable criticism, comments and suggestions to the manuscript. We acknowledge the practical help of B. Hellemans from the Catholic University of Leuven with picogreen analysis. This work was partially financed by the Belgian government (BELSPO Action $1 \mathrm{MO} / 37 / 022$ to JDP and JEMU project 2006A50820.002).

\section{REFERENCES}

AARVIK L. \& KARISCH T. 2009: Revision of Multiquaestia Karisch (Lepidoptera: Tortricidae: Grapholitini). Zootaxa 2026: $18-32$.

ADAMSKI D. \& BRown R.L. 1989: Morphology and systematics of North American Blastobasidae (Lepidoptera: Gelechioidea). Mississippi Agric. Forest. Exp. Stat. Techn. Bull. 165: $1-70$.

Amsel H.-G. 1935: Comment préparer les microlépidoptères secs. Amat. Papillons 7: 238-240.

Bucheli S.R. \& Wenzel J.W. 2005: Gelechioidea (Insecta: Lepidoptera) systematics: A reexamination analysis using combined morphology and mitochondrial DNA data. Mol. Phylogen. Evol. 35: 380-394.

Burns J.M., Janzen D.H., Hajibabaei M., Hallwachs W. \& HeBert P.D.N. 2007: DNA barcodes of closely related (but morphologically and ecologically distinct) species of skipper butterflies (Hesperiidae) can differ by only one to three nucleotides. J. Lepid. Soc. 61: 138-153.
Carter D.J., Vogler A.P. \& Vane-Wright R.I. 1997: Notes on basic collecting techniques for morphological studies of Lepidoptera. Metamorphosis 8: 99-106.

Dall'Asta U., De Prins J. \& De Prins W. 2002: Récolte de Microlépidoptères au Kenya, avec description d'une méthode de préparation. Bull. Soc. R. Belge Entomol. 138: 106-111.

Davis D.R. \& Stonis J.R. 2007: A revision of the new world plant-mining moths of the family Opostegidae (Lepidoptera: Nepticuloidea). Smiths. Contrib. Zool. 625: 1-212.

De Prins J., Mozuraitis R., Lopez-Vaamonde C. \& Rougerie R. 2009: Sex attractant, distribution and DNA barcodes for the Afrotropical leaf-mining moth Phyllonorycter melanosparta (Lepidoptera: Gracillariidae). Zootaxa 2281: 53-67.

DeschKa G. \& Dimic N. 1986: Cameraria ohridella sp. n. (Lep., Lithocolletidae) aus Mazedonien, Jugoslavien. Acta Entomol. Jugoslav. 22: 11-23.

Folmer O., Black M., Hoeh W., Lutz R. \& Vrijenhoek R. 1994: DNA primers for amplification of mitochondrial cytochrome c oxidase subunit I from diverse metazoan invertebrates. Mol. Marine Biol. Biotechnol. 3: 294-297.

Gilbert M.T.P., Moore W., Melichior L. \& Worobey M. 2007: DNA extraction from dry museum beetles without conferring external morphological damage. PLoS ONE 2: e272.

HoraK M. 2006: Olethreutine Moths of Australia (Lepidoptera: Tortricidae). Monographs on Australian Lepidoptera. Vol. 10. CSIRO, Collingwood, $522 \mathrm{pp}$.

Janzen D.H., Hajibabaei M., Burns J.M., Halliwachs W., Remigio E.D. \& Heber P.D.N. 2005: Wedding biodiversity inventory of a large and complex Lepidoptera fauna with DNA barcoding. Phil. Trans. R. Soc. (B, Biol. Sci.) 360: 1835-1845.

KAILA L. 2011: Elachistine moths of Australia (Lepidoptera: Gelechioidea: Elachistidae). Monographs on Australian Lepidoptera. Vol. 11. CSIRO Publishing, Collingwood, 443 pp.

KaILA L. \& STÅhls G. 2006: DNA barcodes: Evaluating the potential of COI to differentiate closely related species of Elachista (Lepidoptera: Gelechioidea: Elachistidae) from Australia. Zootaxa 1170: 1-26.

Kawahara A.Y., Ohshima I., Kawakita A., Regier J.C., Mitter M.P., Cummings D.R., Davis D.L., Wagner J., De Prins J. \& Lopez-VAamonde C. 2011: Increased gene sampling provides stronger support for higher-level groups within gracillariid leaf mining moths and relatives (Lepidoptera: Gracillariidae). BMC Evol. Biol. 11: 182-196.

Kawakita A., Takimura A., Terachi T., Sota T. \& Kato M. 2004: Cospeciation analysis of an obligate pollination mutualism: have Glochidion trees (Euphorbiaceae) and Epicephala moths (Gracillariidae) diversified in parallel? Evolution 58: 2201-2214.

Knölke S., Erlacher S., Hausmann A., Miller M.A. \& Segerer A. 2005: A procedure for combined genitalia dissection and DNA extraction in Lepidoptera. Insect Syst. Evol. 35: 401-409.

Koscinski D., Crawford L.A., Keller H.A. \& Keyghobadi N. 2011: Effects of different methods of non-lethal tissue sampling on butterflies. Ecol. Entomol. 36: 301-308.

Kristensen N.P., Scoble M.J. \& Karsholt O. 2007: Lepidoptera phylogeny and systematics: the state of inventorying moth and butterfly diversity. Zootaxa 1698: 699-747.

Küper W., Sommer J.H., Lovett J.C., Mutke J., Linder H.P., Beentje H.J., Van Rompaey R.A.S.R., Chatelain C., SosefF M. \& BARThlotT W. 2004: Africa's hotspots of biodiversity redefined. Ann. Missouri Botan. Garden 91: 525-535.

Lai B.C.G. \& Pullin A.S. 2004: Phylogeography, genetic diversity and conservation of the large copper butterfly Lycaena dispar in Europe. J. Insect Conserv. 8: 27-35. 
LANDRY J.-F. \& LANDRY B. 1984: A technique for setting and mounting microlepidoptera. J. Lepid. Soc. 48: 205-227.

Lees D.C., Lopez-Vaamonde C. \& Augustin S. 2011a: Taxon page for Cameraria ohridella Deschka \& Dimic 1986. In: EOLspecies, http://eolspecies.lifedesks.org/pages/8675.

Lees D.C., Lack H.W., Rougerie R., Hernandez A., Raus T., Avtzis N.D., Augustin S. \& Lopez-VaAmonde C. 2011b: Tracking origins of invasive herbivores using herbaria and archival DNA: the case of the horse-chestnut leafminer. Front Ecol. Environ. 9: 322-328.

Lopez-VAamonde C., Godfray H.C.J. \& CoOK J.M. 2003: Evolutionary dynamics of host-plant use in a genus of leaf-mining moths. Evolution 57: 1804-1821.

Lopez-Vaamonde C., Wikström N., Labandeira C., Godfray H.C., Goodman S.J. \& CooK J.M. 2006: Fossil-calibrated molecular phylogenies reveal that leaf-mining moths radiated several million years after their host plants. J. Evol. Biol. 19: $1314-1326$.

MANDRIOLI M. 2008: Insect collections and DNA analyses: how to manage collections? Mus. Manag. Curatorship 23: 193-199.

Mandrioli M., Borsatti F. \& Mola L. 2006: Factors affecting DNA preservation from museum-collected lepidopteran specimens. Entomol. Exp. Appl. 120: 239-244.

Mari Mena N., Valade R., Magnoux E., Augustin S. \& LopezVAamonde C. 2008: Microsatellites for the highly invasive Cameraria ohridella (Lepidoptera: Gracillariidae) and their amplification in related species. Eur. J. Entomol. 105: 945-948.

McDonald J.H. 2009: Handbook of Biological Statistics. 2nd ed. Sparky House Publishing, Baltimore, MD, 293 pp.

Meusnier I., Singer G.A.C., Landry J.F., Hickey D.A., Hebert P.D.N. \& HaJibabaei M. 2008: A universal DNA minibarcode for biodiversity analysis. BMC Genomics 9: 214 .

Mutanen M., Wahlberg N. \& Kaila L. 2010: Comprehensive gene and taxon coverage elucidates radiation patterns in moths and butterflies. Proc. R. Soc. (B) 277: 2839-2848.

NieUKerKen E.J. van 2007: Acalyptris Meyrick: revision of the platani and staticis groups in Europe and the Mediterranean (Lepidoptera: Nepticulidae). Zootaxa 1436: 1-48.

NIEUKERKEN E.J. vAN 2010: Order Lepidoptera, family Nepticulidae. In van Harten A. (ed.): Arthropod Fauna of the UAE. Vol. 2. Dar Al Ummah, Abu Dhabi, pp. 392-514.

NieUKerken E.J. van, Kaila L., Kitching I.J., Kristensen N.P., Lees D.C., Minet J. et al.: Order Lepidoptera Linnaeus, 1758. In Zhang Z.-Q. (ed.): Animal biodiversity: An outline. Zootaxa (in press).

Oнshima I. 2008: Host race formation in the leaf-mining moth Acrocercops transecta (Lepidoptera: Gracillariidae). Biol. J. Linn. Soc. 93: 135-145.

Ohshima I. \& Yoshizawa K. 2006: Multiple host shifts between distantly related plants, Juglandaceae and Ericaceae, in the leaf-mining moth Acrocercops leucophaea complex (Lepidoptera: Gracillariidae). Mol. Phylogen. Evol. 38: 231-240.

Pellmyr O., Balcazar-Lara M., Althoff D.M., Segraves K.A. \& Leebens-Mack J. 2005: Phylogeny and life history evolution of Prodoxus yucca moths (Lepidoptera: Prodoxidae). Syst. Entomol. 31: 1-20.

Phillips A.J. \& Simon C. 1995: Simple, efficient, and nondestructive DNA extraction protocol for arthropods. Ann. Entomol. Soc. Am. 88: 281-283.

Post R.J., Flook P.K. \& Millest A.L. 1993: Methods for the preservation of insects for DNA studies. Biochem. Syst. Ecol. 21: 85-92.

Quicke D.L.J., Belshaw R. \& Lopez-Vaamonde C. 1999: Preservation of hymenopteran specimens for subsequent molecular and morphological study. Zool. Scripta 28: 261-267.
Regier J.C., Zwick A., Cummings M.P., Kawahara A.Y., Cho S., Weller S., Roe A., Baixeras J., Brown J.W., Parr C., Davis D.R., Epstein M., Hallwachs W., Hausmann A., Janzen D.H., Kitching I.J., Solis M.A., Yen S.H., Bazinet A.L. \& MitTeR C. 2009: Toward reconstructing the evolution of advanced moths and butterflies (Lepidoptera: Ditrysia): an initial molecular study. BMC Evol. Biol. 9: 280.

Rose O.C., Brookes M.I. \& Mallet J.L.B. 1994: A quick and simple non-lethal method for extracting DNA from butterfly wings. Mol. Ecol. 3: 275.

Rowley D.L., Coddington J.A., Gates M.W., Norrbom A.L., Ochoa R.A., Vandenberg N.J. \& Greenstone M.H 2007: Vouchering DNA-barcoded specimens: test of a nondestructive extraction protocol for terrestrial arthropods. Mol. Ecol. Notes 7: 915-924.

Schmitz P., Cibois A. \& LandRy B. 2007: Molecular phylogeny and dating of an insular endemic moth radiation inferred from mitochondrial and nuclear genes: the genus Galagete (Lepidoptera: Autostichidae) of the Galápagos islands. Mol. Phylogen. Evol. 45: 180-192.

Schmitz P., Cibors A. \& Landry B. 2008: Cryptic differentiation in the endemic micro-moth Galagete darwini (Lepidoptera, Autostichidae) on Galápagos volcanoes. Phil. Transact. R. Soc. (B) 363: 3453-3458.

Singer-Sam J., Tanguay R.C. \& Riggs A.D. 1989: Use of Chelex to improve the PCR signal from a small number of cells. Amplifications 3: 11.

Valade R., Kenis M., Hernandez-Lopez A., Augustin S., Mari Mena N., Magnoux E., Rougerie R., Lakatos F., Roques A. \& LOPEZ-VAAMONDE C. 2009: Mitochondrial and microsatellite DNA markers reveal a Balkan origin for the highly invasive Horse-Chestnut leaf miner Cameraria ohridella (Lep. Gracillariidae). Mol. Ecol. 18: 3458-3470.

VÁRI L. 1961: South African Lepidoptera. Vol. 1. Lithocolletidae. Transv. Mus. Memoir 12: i-xix, 1-238, 112 pls.

Vila M., Auger-Rozenberg M.A., Goussard F. \& LopezVAAMONDE C. 2009: Effect of non-lethal sampling on lifehistory traits of the protected moth Graellsia isabelae (Lepidoptera: Saturniidae). Ecol. Entomol. 34: 356-362.

Vink C.J., Thomas S.M., Paquin P., Hayashi C.Y. \& Hedin M. 2005: The effects of preservatives and temperatures on arachnid DNA. Invert. Syst. 19: 99-104.

WAHLBerg N. \& WheAt C.W. 2008: Genomic outposts serve the phylogenomic pioneers: designing novel nuclear markers for genomic DNA extractions of Lepidoptera. Syst. Biol. 57: 231-242.

Walsh P.S., Metzger D.A. \& Higuchi R. 1991: Chelex 100 as a medium for simple extraction of DNA for PCR-based typing from forensic material. Biotechniques 10: 506-513.

Watts P.C., Thompson D.J., Daguet C. \& Kemp S.J. 2005: Exuviae as a reliable source of DNA for population-genetic analysis of odonates. Odonatologica 34: 183-187.

Watts P.C., Thompson D.J., Allen K.A. \& Kemp S.J. 2007: How useful is DNA extracted from the legs of archived insects for microsatellite-based population genetic analyses? J. Insect Conserv. 11: 195-198.

Wilding C.S., Weetman D., Steen K. \& Donnely M.J. 2009: Accurate determination of DNA yield from individual mosquitoes for population genomic applications. Insect Sci. 16: 361-363.

Whitfield J.B. \& CAmeron S.A. 1994: Museum policies concerning specimen loans for molecular systematic research. Mol. Phylogen. Evol. 3: 268-278.

Received June 17, 2011; revised and accepted August 25, 2011 